University of Nebraska - Lincoln

DigitalCommons@University of Nebraska - Lincoln

Nebraska Cooperative Fish \& Wildlife Research Nebraska Cooperative Fish \& Wildlife Research Unit -- Staff Publications

$4-2020$

\title{
Understanding Sportsperson Retention and Reactivation Through License Purchasing Behavior
}

\author{
Matthew P. Hinrichs \\ U.S. Department of Agriculture, matthewphinrichs@gmail.com \\ Nathaniel B. Price \\ University of Nebraska - Lincoln, nprice3@unl.edu \\ Matthew P. Gruntorad \\ University of Nebraska - Lincoln, mgruntorad2@unl.edu \\ Kevin L. Pope \\ USGS-NCFWRU, kpope2@unl.edu \\ Joseph J. Fontaine \\ University of Nebraska-Lincoln, jfontaine2@unl.edu
}

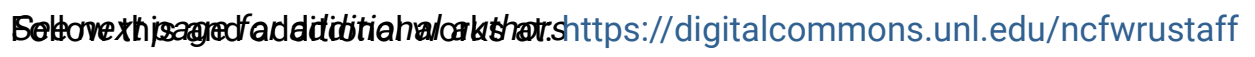

Part of the Aquaculture and Fisheries Commons, Environmental Indicators and Impact Assessment Commons, Environmental Monitoring Commons, Natural Resource Economics Commons, Natural

Resources and Conservation Commons, and the Water Resource Management Commons

Hinrichs, Matthew P.; Price, Nathaniel B.; Gruntorad, Matthew P.; Pope, Kevin L.; Fontaine, Joseph J.; and Chizinski, Christopher J., "Understanding Sportsperson Retention and Reactivation Through License Purchasing Behavior" (2020). Nebraska Cooperative Fish \& Wildlife Research Unit -- Staff Publications. 295.

https://digitalcommons.unl.edu/ncfwrustaff/295

This Article is brought to you for free and open access by the Nebraska Cooperative Fish \& Wildlife Research Unit at DigitalCommons@University of Nebraska - Lincoln. It has been accepted for inclusion in Nebraska Cooperative Fish \& Wildlife Research Unit -- Staff Publications by an authorized administrator of DigitalCommons@University of Nebraska - Lincoln. 


\section{Authors}

Matthew P. Hinrichs, Nathaniel B. Price, Matthew P. Gruntorad, Kevin L. Pope, Joseph J. Fontaine, and Christopher J. Chizinski 
Original Article

\title{
Understanding Sportsperson Retention and Reactivation Through License Purchasing Behavior
}

\author{
MATTHEW P. HINRICHS, ${ }^{1}$ U.S. Department of Agriculture, NRCS, Salem, SD 57058, USA, and School of Natural Resources, University of \\ Nebraska, Lincoln, NE 68583, USA \\ NATHANIEL B. PRICE, School of Natural Resources, University of Nebraska, Lincoln, NE 68583, USA \\ MATTHEW P. GRUNTORAD, School of Natural Resources, University of Nebraska, Lincoln, NE 68583, USA \\ KEVIN L. POPE, U.S. Geological Survey—Nebraska Cooperative Fish and Wildlife Research Unit, and School of Natural Resources, University of \\ Nebraska, Lincoln, NE 68583, USA \\ JOSEPH J. FONTAINE, Nebraska Cooperative Fish and Wildlife Research Unit, and School of Natural Resources, University of Nebraska, Lincoln, \\ NE 68583, USA \\ CHRISTOPHER J. CHIZINSKI, School of Natural Resources, University of Nebraska, Lincoln, NE 68583, USA
}

\begin{abstract}
Most state and provincial fish and wildlife agencies have access to important information about patterns in sportsperson participation through their license databases. Using transaction data from Nebraska Game and Parks Commission's electronic hunting and fishing license system, we tracked license purchases of Nebraska, USA, resident license holders in 2010 through 2017. We categorized sportspersons by gender and yearly purchases as hunting only (Hunter), fishing only (Angler), a combination of hunting and fishing (Hunter-Angler), or no purchases (Inactive). The probability of movement among active sportsperson groups was limited and varied little based on initial group participation. The Angler group had the greatest probability of an individual transitioning to the Inactive group (females $=0.39$; males $=0.33$ ). The Hunter-Angler group had the greatest probability of an individual remaining within the same group (females $=0.65$; males $=0.76$ ). There was a relatively low probability of an individual in the Hunter group moving to the Angler group and vice versa $(\leq 0.02)$. The sportsperson population is dynamic and understanding patterns of sportsperson participation is important for the future of fish and wildlife management in North America. Using data readily available to most fish and wildlife agencies has the potential to significantly improve our understanding of hunter and angler participation and aid management agencies and conservation organizations in the development of more effective strategies for managing sportspersons. (C) 2020 The Wildlife Society.
\end{abstract}

KEY WORDS electronic license database, hunting, license purchases, Markov chain modeling, recreational fishing.

Concern over declining participation in hunting and fishing (U.S. Fish and Wildlife Service 1993, 2018) and future funding for fish and wildlife management (Vrtiska et al. 2013, Winkler and Warnke 2013) has led to increased efforts to understand the motivations, preferences, satisfactions, demographics, and potential constraints of participants in recreational hunting and fishing (i.e., sportspersons). Increased application of social surveys (e.g., mail, in-person, web) of sportspersons (e.g., Kuehn et al. 2013, Laborde et al. 2014, Quartuch et al. 2016) has greatly improved our knowledge of participation, and social surveys are critical for garnering support of agency programs and management efforts

Received: 20 August 2018; Accepted: 22 December 2019

Published: 21 April 2020

${ }^{1}$ E-mail: matthewphinrichs@gmail.com
(Price Tack et al. 2018). Yet costs associated with regularly surveying sportspersons brings into question the long-term viability of only using survey efforts (Roberts 2007). Moreover, surveys may not be well-suited to capture periods of repeated behavior of individuals (e.g., recall bias and nonresponse bias; Rogelberg and Stanton 2007, Fontaine et al. 2019). Further, repeatedly surveying participants can lead to survey fatigue and result in reduced response rates and careless responding because sportspersons are burdened with answering multiple surveys (Meade and Craig 2012, Huang et al. 2014, Callegaro and Yang 2018). As costs of surveys increase and response rates decrease, it is important for state and provincial fish and wildlife agencies to develop new approaches to understand sportsperson participation (Galea and Tracy 2007).

Most state and provincial fish and wildlife agencies already have access to important information about patterns in 
sportsperson participation through their license databases. Tracking sportspersons using individual customer identification numbers can reveal patterns in recruitment (first-time purchase of a hunting or fishing license), retention (continued purchase of licenses across multiple years), and reactivation (purchase of a license after several years with no purchases). Recruitment, retention, and reactivation (R3) are integral components of efforts designed to increase participation in hunting and fishing (Responsive Management and National Shooting Sports Foundation 2017). State and provincial wildlife agencies have made it a priority to increase hunting participation with an abundance of alternative approaches, such as youth hunts, regulation and license price changes, and mentor and educational programs (Ryan and Shaw 2011, Responsive Management and National Shooting Sports Foundation 2017). Despite the increased efforts to promote hunting and fishing, there is little effort to coordinate and evaluate R3 programs being implemented (Council to Advance Hunting and the Shooting Sports 2016, Price Tack et al. 2018).

License databases may help fish and wildlife agencies further understand sportsperson participation, but unfortunately agencies do not have a strong grasp of purchasing patterns and how they may fit into R3 objectives. Sportspersons often transition between hunting and fishing activities, sometimes substituting preferred activities with alternative hunting or fishing opportunities (Baumgartner and Heberlein 1981, Vaske et al. 1990, Ditton and Sutton 2004), or many times participating in multiple activities within the same year (e.g., Miller and Graefe 2000). Understanding patterns of participation within and among alternative hunting and fishing activities can therefore greatly improve our understanding of sportsperson participation. To exemplify the ease by which fish and wildlife agencies can facilitate their understanding of patterns of sportsperson participation using data they already possess, we used license purchase data from Nebraska, USA, to assess transitions among alternative hunting and fishing activities. We limited our assessment to the purchase of permits and license sales only, whereby a permit allows a user to pursue a particular species and a license allows a user to pursue multiple species (e.g., small game). Speciesspecific hunting permits include deer (Odocoileus spp.), which are species-, sex-, and harvest-method-specific (e.g., archery, muzzleloader), and wild turkeys (Meleagris gallopavo), with separate seasons occurring in the spring and autumn. An annual fishing license or hunt-and-fish combination license is valid for a single calendar year and allows an angler to pursue multiple fish species throughout the calendar year, each with specific daily limits. Similarly, the purchase of a small game or hunt-and-fish combination license allows a hunter to pursue multiple small game species, each with specific seasons and daily limits, and sometimes with additional purchase requirements (i.e., Federal waterfowl stamp).

Employing techniques used by business on "big transactional data" (Callegaro and Yang 2018), we attempted to address several objectives aimed at improving our understanding of Nebraska sportspersons. Specifically, our objectives were to estimate the probability of female and male sportspersons transitions 1) among Hunter, Angler, and Hunter-Angler groups; 2) from Active to Inactive (not purchase license or permit); and 3) from Inactive to Active (purchase a license or permit following a year with no purchase). Ultimately, understanding purchase tendencies among license or permit holders will aid management agencies in the development of strategies for more effective management of sportspersons.

\section{METHODS}

\section{Electronic License Data}

We analyzed transaction data from the Nebraska Game and Parks Commission's (NGPC) electronic license system. We focused our assessment on Nebraska female and male residents who purchased hunting-only (Hunter), fishing-only (Angler), or a combination of hunting and fishing (Hunter-Angler) licenses and permits in the 2010 licenseand-permit year and their subsequent purchases each year through 2017. Nonresidents have much larger churn rates (Southwick Associates 2015b) and including them in the sample would confound estimates due to residency. In addition, the license-and-permit years chosen can potentially have some influence on the estimated transition probabilities based on inherent cohort dynamics. We focused on the 2010 license-and-permit year because this provided us the greatest timeframe to estimate our transition probabilities given the restrictions of the Nebraska electronic license system (i.e., full digital records for all license and permit types included in this study started in 2010). If an individual did not make a purchase during the 2010 license-and-permit year, we did not include them in the analysis. The Hunter group included individuals who purchased any combination of deer permits, turkey permits, or small game licenses, but not a fishing license. The Angler group included all individuals who purchased a fishing license, but no hunting licenses or permits of any type. Finally, the Hunter-Angler group purchased either a huntand-fish combination license (small game and fishing) or a general fishing license and any hunting license or permit. We did not include multiyear licenses in our sample because they were not offered in Nebraska until 2013. In addition, we did not include lifetime license holders because there were relatively few in 2010 ( $N=29$; J. Young, Nebraska Game and Parks Commission, personal communication). Further, focusing on annual licenses provided us better estimates of year-to-year changes in purchasing behavior among sportspersons. We considered transitions among license-and-permit years; these mirror the calendar year (1 Jan to $31 \mathrm{Dec}$ ) except for some deer and all autumn turkey permits, which include a late hunting season in January of the following calendar year.

\section{Analysis}

We modelled sportspersons transition probabilities $(P=0$ to 1$)$ among groups using a discrete-time Markov chain model (Winston 1994), which is a stochastic model describing a 
sequence of possible events in discrete time and space (Karlin and Taylor 1975). The assumptions of the Markov chain model are the transition probabilities between any 2 groups depend only on the current groups (i.e., does not depend on history), and transition probabilities are not changing over time (i.e., time homogenous; Collet 2018). Furthermore, application of the model assumes the sportsperson population is homogenous (i.e., group transition probabilities are the same).

We tracked subsequent resident license and permit purchases by the 2010 cohort through 2017 using unique customer identifiers generated by NGPC. The NGPC has data-cleaning protocols to minimize duplicated customer identifiers. All research protocols and techniques complied with University of Nebraska-Lincoln Institutional Review Board requirements (IRB Approval \#: 20160616155 EP) and NGPC policies.

Each year, we categorized an individual by gender and as a Hunter (H), Angler (A), combination Hunter-Angler (C), or 1 of 7 Inactive (I) groups. The inactive groups were first year with no purchase $\left(\mathrm{I}_{1}\right)$, second year $\left(\mathrm{I}_{2}\right)$, third year $\left(\mathrm{I}_{3}\right)$, fourth year $\left(\mathrm{I}_{4}\right)$, fifth year $\left(\mathrm{I}_{5}\right)$, sixth year $\left(\mathrm{I}_{6}\right)$, and seventh year $\left(I_{7}\right)$. All 10 groups were exhaustive (i.e., included all possible groups) and mutually exclusive, such that every individual's annual purchases during the 8-year period were concisely represented in one of the groups. An individual could move among the active groups (Hunter, Angler, and Hunter-Angler) and from any active group into the firstyear inactive group $\left(\mathrm{I}_{1}\right)$. We defined the inactive groups $\left(\mathrm{I}_{1}-\mathrm{I}_{7}\right)$ sequentially such that an individual either progressed one step to the next inactive group or returned to an active group. We used the Markov chain package in Program R to estimate the transition matrix using maximum likelihood estimation (Spedicato 2017, R Core Team 2018). The transition matrix, $P$, defines the probabilities of moving between any 2 groups. Each element of the transition matrix, $P_{i j}$, is the number of times a transition was observed from group $i$ to group $j$, divided by the total number of observed transitions originating from group $i$.

Violations of the Markov chain model assumptions may result in a poor model fit. To assess model fit, we used simulation-based model checking that is similar to posterior predictive checking under a Bayesian framework (Gelman and Shalizi 2013). The basic reasoning of simulation-based model checking is that if the model describes how data could have been generated, then synthetic data simulated from the fitted model should be similar to the real, observed data. We performed a simulation to reconstruct the original purchase histories indicating the group for each customer over time. We performed the simulation conditional on knowing the starting group of each individual (i.e., Hunter, Angler, or Hunter-Angler). For each customer, we performed a random draw from a multinomial distribution to determine which group the customer would move to the following year (e.g., a die roll). We repeated this process for all individuals and all years. We compared the simulated purchase histories with the observed purchase histories to quantify the model fit. We visually compared the predicted number of individuals in each group over time to the observed number of individuals in each group and calculated the root-mean-square error (RMSE), mean-absolutepercentage error (MAPE), and the coefficient of determination $\left(R^{2}\right)$. The determination of whether the model fit is reasonable should consider various error metrics, how the model will be used in decision-making, and tolerance for uncertainty or error in those decisions.

\section{RESULTS}

In 2010, of the 218,410 Nebraska residents that purchased a hunting or fishing license or permit, $18 \%$ were female. Among female sportspersons, $70 \%$ were in the Angler group, $19 \%$ were in the Hunter group, and $11 \%$ were in the Hunter-Angler group. Among male sportspersons, 34\% were in the Angler group, 34\% were in the Hunter group, and 32\% were in the Hunter-Angler group. Between 2010 and 2017, the 2010 resident license or permit cohort purchased roughly 4.5 million licenses and permits.

Among females, the Hunter-Angler group had 0.35 probability of transitioning to a different group, the Hunter group had 0.39 with a probability of transitioning to a different group, and the Angler group had a 0.43 probability of transitioning to a different group (Table 1; Fig. 1). Among males, the Hunter-Angler group had 0.25 probability of transitioning to a different group, the Hunter group had 0.33 with a probability of transitioning to a different group, and the Angler group had a 0.42 probability of transitioning to a different group (Table 1; Fig. 2). Transition to the inactive group from the active group varied depending on the group. Females from the Hunter-Angler group had the least (0.18) probability of transitioning to the inactive group and the Angler group had the greatest (0.39). Similarly, males from the Hunter-Angler group had the least (0.09) probability of transitioning to the inactive group and the Angler group had the greatest (0.33) probability of transitioning to the inactive group (Table 2; Figs. 1 and 2). Transitions between active sportspersons groups were relatively minimal for female $(\leq 0.09)$ and male $(\leq 0.11)$ sportspersons. Female sportspersons in the first-year inactive group $\left(\mathrm{I}_{1}\right)$ had a 0.75 probability of transitioning to the second-year inactive group $\left(\mathrm{I}_{2}\right)$; each subsequent inactive

Table 1. The probabilities of female and male license or permit holders transitioning between active sportsperson groups, based on Nebraska, USA, resident license transaction data from Nebraska Game and Parks Commission's electronic hunting and fishing license system from 2010 through 2017. The active groups are Hunter (H), Angler (A), and Hunter-Angler (C).

\begin{tabular}{|c|c|c|c|c|c|}
\hline \multirow{2}{*}{$\begin{array}{l}\text { From } \\
\text { group }\end{array}$} & \multirow[b]{2}{*}{ To group } & \multicolumn{2}{|c|}{ Female } & \multicolumn{2}{|c|}{ Male } \\
\hline & & & $\pm 95 \%$ CI & & $\pm 95 \% \mathrm{CI}$ \\
\hline A & A & 0.57 & 0.005 & 0.58 & 0.003 \\
\hline A & C & 0.03 & 0.001 & 0.08 & 0.001 \\
\hline A & $\mathrm{H}$ & 0.01 & 0.001 & 0.02 & 0.001 \\
\hline C & A & 0.08 & 0.003 & 0.05 & 0.001 \\
\hline $\mathrm{C}$ & C & 0.65 & 0.010 & 0.75 & 0.003 \\
\hline C & $\mathrm{H}$ & 0.09 & 0.004 & 0.11 & 0.001 \\
\hline $\mathrm{H}$ & A & 0.02 & 0.002 & 0.02 & 0.001 \\
\hline $\mathrm{H}$ & C & 0.09 & 0.004 & 0.13 & 0.001 \\
\hline $\mathrm{H}$ & $\mathrm{H}$ & 0.61 & 0.009 & 0.67 & 0.003 \\
\hline
\end{tabular}




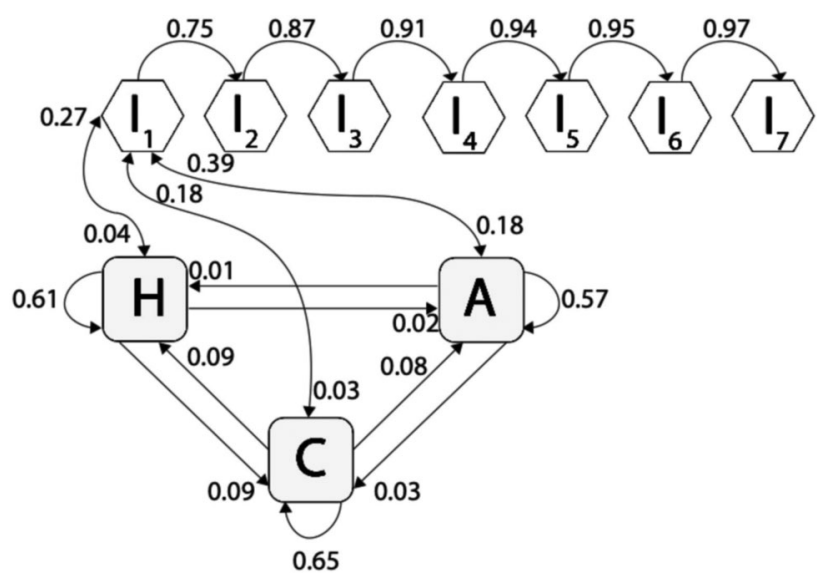

Figure 1. Flow diagram of transitioning among active (Hunter $[\mathrm{H}]$, Angler [A], Hunter-Angler [C]), and inactive (first year with no purchase $\left[\mathrm{I}_{1}\right]$, second year $\left[\mathrm{I}_{2}\right]$, third year $\left[\mathrm{I}_{3}\right]$, fourth year $\left[\mathrm{I}_{4}\right]$, fifth year $\left[\mathrm{I}_{5}\right]$, sixth year $\left[I_{6}\right]$, and seventh year $\left[I_{7}\right]$ ) groups of Nebraska, USA, resident female sportspersons. Analysis based on license transaction data from Nebraska Game and Parks Commission's electronic hunting and fishing license system, from 2010 through 2017. Arrows indicate transition paths and numbers indicate probabilities to transition between groups. Not all transitions are illustrated to enhance readability of the figure, but all transitions probabilities are provided (Tables 1, 2, 3).

transition probability increased, with a 0.97 probability of transitioning to the seventh-year inactive group ( $\mathrm{I}_{7}$; Table 3 ; Fig. 1). Male sportspersons in the first-year inactive group $\left(\mathrm{I}_{1}\right)$ had a 0.67 probability of transitioning to the secondyear inactive group $\left(\mathrm{I}_{2}\right)$; each subsequent inactive transition probability increased, with a 0.95 probability of transitioning to the seventh-year inactive group $\left(\mathrm{I}_{7}\right.$ [Table 3 ; Fig. 2]). The estimated probability that a female sportsperson becomes inactive and remains inactive (i.e., drop out) from the Hunter, Angler, and Hunter-Angler groups were $0.14,0.20$, and 0.09 , respectively. The estimated probability

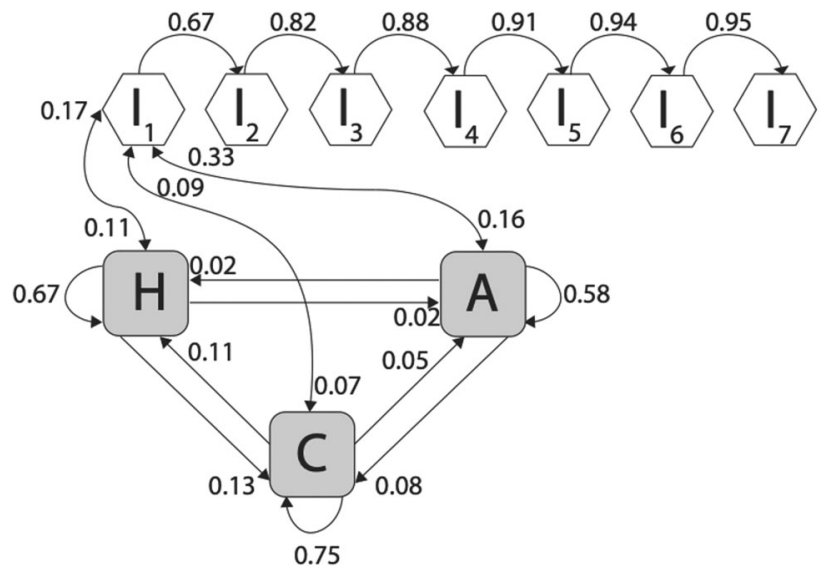

Figure 2. Flow diagram of transitioning among active (Hunter $[\mathrm{H}]$, Angler [A], Hunter-Angler [C]), and inactive (first year with no purchase $\left[\mathrm{I}_{1}\right]$, second year $\left[\mathrm{I}_{2}\right]$, third year $\left[\mathrm{I}_{3}\right]$, fourth year $\left[\mathrm{I}_{4}\right]$, fifth year $\left[\mathrm{I}_{5}\right]$, sixth year $\left[\mathrm{I}_{6}\right]$, and seventh year $\left[\mathrm{I}_{7}\right]$ ) groups of Nebraska, USA, resident male sportspersons. Analyses based on license transaction data from Nebraska Game and Parks Commission's electronic hunting and fishing license system from 2010 through 2017. Arrows indicate transition paths and numbers indicate probabilities to transition between groups. Not all transitions are illustrated to enhance readability of the figure, but all transitions probabilities are provided (Tables 1, 2, 3).
Table 2. The probabilities of active of Nebraska, USA, resident female and male license or permit holders transitioning to inactive group, based on license transaction data from Nebraska Game and Parks Commission's electronic hunting and fishing license system from 2010 through 2017. The active groups are Hunter (H), Angler (A), and Hunter-Angler (C). The inactive group $I_{1}$ corresponds to a single year without purchase.

\begin{tabular}{lcccccc}
\hline \multirow{2}{*}{$\begin{array}{l}\text { From } \\
\text { group }\end{array}$} & & To group & & $\mathbf{\pm 9 5 \% ~ C I}$ & & $\mathbf{2 9 5 \% ~ C I ~}$ \\
\cline { 3 - 4 } \cline { 6 - 7 } \cline { 6 - 7 } & $\mathrm{I}_{1}$ & 0.39 & 0.004 & & 0.33 & 0.002 \\
$\mathrm{C}$ & $\mathrm{I}_{1}$ & 0.18 & 0.005 & & 0.09 & 0.001 \\
$\mathrm{H}$ & $\mathrm{I}_{1}$ & 0.27 & 0.006 & & 0.17 & 0.002 \\
\hline
\end{tabular}

that a male sportsperson drops out from the Hunter, Angler, and Hunter-Angler groups were 0.07, 0.13, and 0.03, respectively.

We quantified model fit at 2 levels: 1) number of customers in each group over time, and 2) number of individuals with each possible purchase history. The model predicted the number of individuals in each group over time reasonably well (Females: $\mathrm{RMSE}=1,539, \mathrm{MAPE}=19 \%, R^{2}=0.89$; Males: $\mathrm{RMSE}=3,990, \mathrm{MAPE}=14 \%, R^{2}=0.93$ ). Over time, the number of individuals in the active groups declined as individuals moved into the initially empty inactive groups (Figs. 3 and 4). The decline was largest in the Angler group followed by the Hunter group.

The model was less accurate at predicting the number of individuals with each possible purchase history (Females: $\mathrm{RMSE}=56, R^{2}=0.85 ;$ Males: $\mathrm{RMSE}=114, R^{2}=0.73$ ).

Table 3. The probabilities of active of Nebraska, USA, resident female and male license or permit holders returning from an inactive group or remaining inactive the subsequent year, based on license transaction data from Nebraska Game and Parks Commission's electronic hunting and fishing license system from 2010 through 2017. The active groups are Hunter $(\mathrm{H})$, Angler (A), and Hunter-Angler (C). The inactive groups are $\mathrm{I}_{1}$ to $\mathrm{I}_{7}$ corresponding to no purchases for 1 to 7 years.

\begin{tabular}{|c|c|c|c|c|c|}
\hline \multirow{2}{*}{$\begin{array}{l}\text { From } \\
\text { group }\end{array}$} & \multirow[b]{2}{*}{ To group } & \multicolumn{2}{|c|}{ Female } & \multicolumn{2}{|r|}{ Male } \\
\hline & & & $\pm 95 \%$ CI & & $\pm 95 \% \mathrm{CI}$ \\
\hline $\mathrm{I}_{1}$ & A & 0.18 & 0.004 & 0.16 & 0.002 \\
\hline $\mathrm{I}_{1}$ & $\mathrm{C}$ & 0.03 & 0.002 & 0.07 & 0.001 \\
\hline $\mathrm{I}_{1}$ & $\mathrm{H}$ & 0.04 & 0.002 & 0.11 & 0.002 \\
\hline $\mathrm{I}_{1}$ & $\mathrm{I}_{2}$ & 0.75 & 0.008 & 0.67 & 0.004 \\
\hline $\mathrm{I}_{2}$ & A & 0.10 & 0.004 & 0.09 & 0.002 \\
\hline $\mathrm{I}_{2}$ & $\mathrm{C}$ & 0.01 & 0.001 & 0.03 & 0.001 \\
\hline $\mathrm{I}_{2}$ & $\mathrm{H}$ & 0.02 & 0.002 & 0.06 & 0.002 \\
\hline $\mathrm{I}_{2}$ & $\mathrm{I}_{3}$ & 0.87 & 0.011 & 0.82 & 0.006 \\
\hline $\mathrm{I}_{3}$ & A & 0.07 & 0.003 & 0.07 & 0.002 \\
\hline $\mathrm{I}_{3}$ & $\mathrm{C}$ & 0.01 & 0.001 & 0.02 & 0.001 \\
\hline $\mathrm{I}_{3}$ & $\mathrm{H}$ & 0.01 & 0.001 & 0.04 & 0.002 \\
\hline $\mathrm{I}_{3}$ & $\mathrm{I}_{4}$ & 0.91 & 0.012 & 0.88 & 0.007 \\
\hline $\mathrm{I}_{4}$ & A & 0.05 & 0.003 & 0.05 & 0.002 \\
\hline $\mathrm{I}_{4}$ & $\mathrm{C}$ & 0.01 & 0.001 & 0.01 & 0.001 \\
\hline $\mathrm{I}_{4}$ & $\mathrm{H}$ & 0.01 & 0.001 & 0.03 & 0.001 \\
\hline $\mathrm{I}_{4}$ & $\mathrm{I}_{5}$ & 0.94 & 0.014 & 0.91 & 0.009 \\
\hline $\mathrm{I}_{5}$ & A & 0.04 & 0.003 & 0.04 & 0.002 \\
\hline $\mathrm{I}_{5}$ & $\mathrm{C}$ & $<0.01$ & & 0.01 & 0.001 \\
\hline $\mathrm{I}_{5}$ & $\mathrm{H}$ & 0.01 & 0.001 & 0.02 & 0.001 \\
\hline $\mathrm{I}_{5}$ & $\mathrm{I}_{6}$ & 0.95 & 0.016 & 0.94 & 0.011 \\
\hline $\mathrm{I}_{6}$ & A & 0.03 & 0.003 & 0.03 & 0.002 \\
\hline $\mathrm{I}_{6}$ & $\mathrm{C}$ & $<0.01$ & & 0.01 & 0.001 \\
\hline $\mathrm{I}_{6}$ & $\mathrm{H}$ & $<0.01$ & & 0.01 & 0.001 \\
\hline $\mathrm{I}_{6}$ & $\mathrm{I}_{7}$ & 0.97 & 0.019 & 0.95 & 0.013 \\
\hline
\end{tabular}




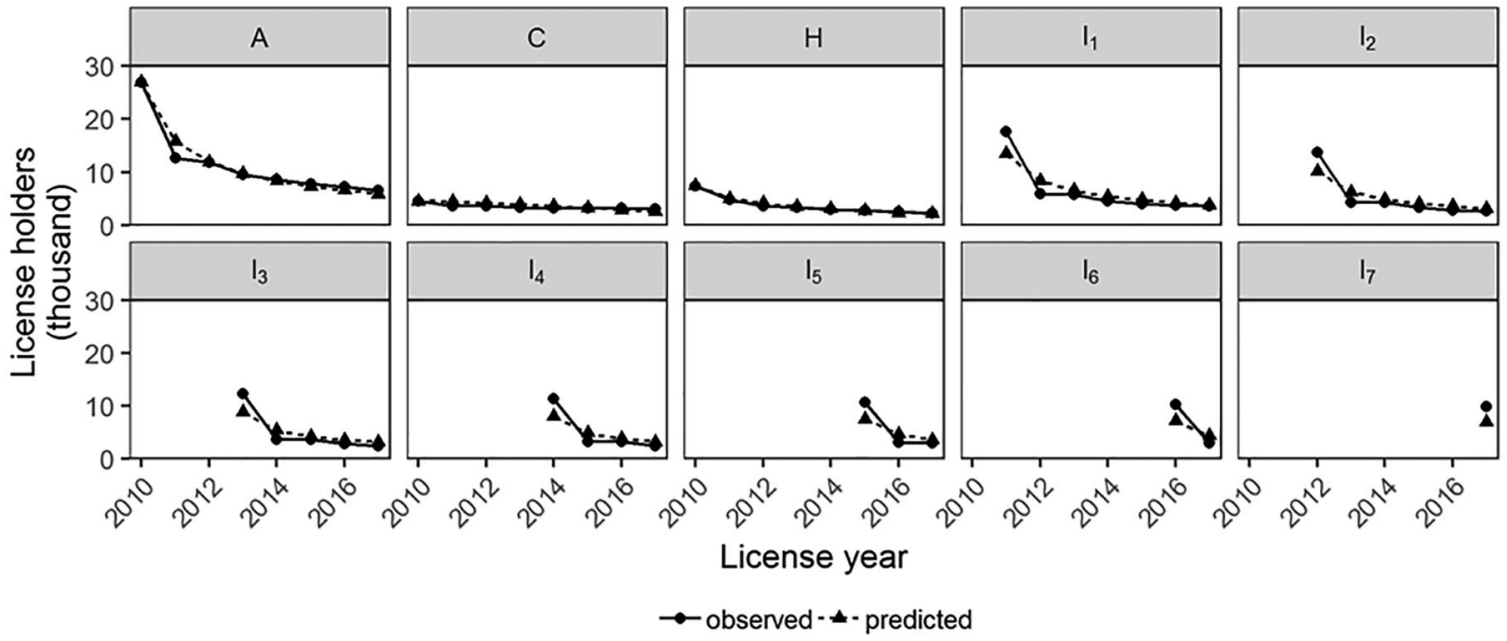

Figure 3. Comparison of predicted ( $\boldsymbol{\Delta}$ dashed line) versus observed ( solid line) numbers of Nebraska, USA, resident female license or permit holders in each group during 2010-2017. The subplots correspond to active (Hunter [H], Angler [A], Hunter-Angler [C]), and inactive (first year with no purchase $\left[\mathrm{I}_{1}\right]$, second year $\left[\mathrm{I}_{2}\right]$, third year $\left[\mathrm{I}_{3}\right]$, fourth year $\left[\mathrm{I}_{4}\right]$, fifth year $\left[\mathrm{I}_{5}\right]$, sixth year $\left[\mathrm{I}_{6}\right]$, and seventh year $\left[\mathrm{I}_{7}\right]$ ) groups of Nebraska, USA, sportspersons. Analysis based on license transaction data from Nebraska Game and Parks Commission's electronic hunting and fishing license system from 2010 through 2017. Predictions are conditional on initial distribution from 2010 ( $n=38,785$ females) and therefore, exactly match the observations in 2010.

The largest underestimation errors occurred for predicting the number of individuals who purchased in the same group every year or purchased once and then did not purchase again. The largest overestimation errors occurred for predicting the number of anglers who purchased 2 or 3 times and then did not purchase again.

\section{DISCUSSION}

Understanding patterns of sportsperson participation is imperative for the future of fish and wildlife management in North America (Responsive Management and National Shooting Sports Foundation 2017). Using a relatively simple time-series approach to license sales data, we demonstrated how agencies can move beyond traditional year-to-year comparisons of license sales or churn to further understand participation patterns of sportspersons, including the allimportant transition to nonparticipation. In general, our results reflect traditional estimates of retention rates for sportspersons (e.g., Southwick Associates and National Shooting Sports Foundation 2010); however, by using a more nuanced approach, we can better identify important details shaping nonparticipation. Gaps between purchases, for example, are relatively common (Southwick Associates 2015a), but traditional estimates of churn fail to distinguish between lapsed sportspersons (i.e., those that will participate again in the future) and those who are indefinitely inactive. The efficacy of reactivation efforts by fish and wildlife agencies can be greatly improved if targeted to individuals

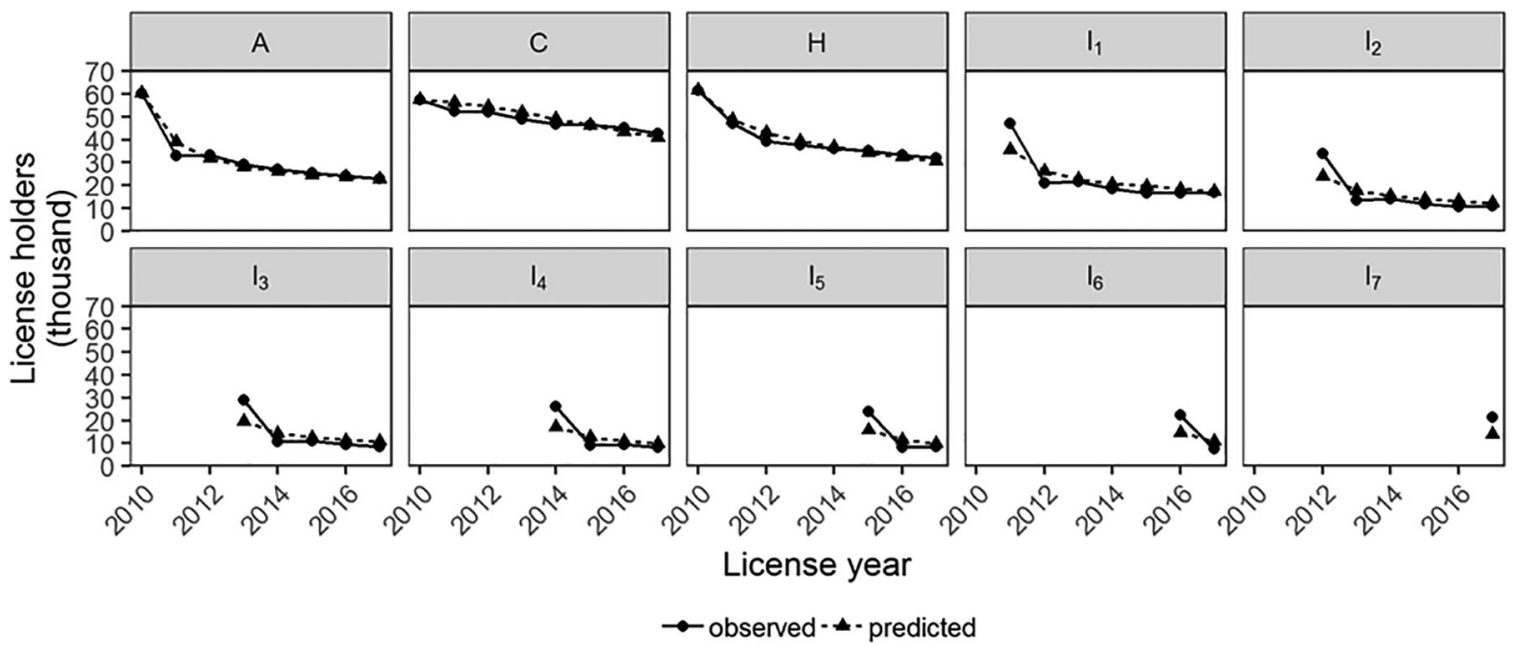

Figure 4. Comparison of predicted ( $\boldsymbol{\Delta}$ dashed line) versus observed ( $\bullet$ solid line) numbers of Nebraska, USA, resident male license or permit holders in each group during 2010-2017. Analysis based on license transaction data from Nebraska Game and Parks Commission's electronic hunting and fishing license system from 2010 through 2017. The subplots correspond to active (Hunter [H], Angler [A], Hunter-Angler [C]), and inactive (first year with no purchase $\left[\mathrm{I}_{1}\right]$, second year $\left[\mathrm{I}_{2}\right]$, third year $\left[\mathrm{I}_{3}\right]$, fourth year $\left[\mathrm{I}_{4}\right]$, fifth year $\left[\mathrm{I}_{5}\right]$, sixth year $\left[\mathrm{I}_{6}\right]$, and seventh year $\left[\mathrm{I}_{7}\right]$ ) groups of Nebraska sportspersons. Predictions are conditional on initial distribution from $2010(n=179,625$ males $)$ and therefore exactly match the observations in 2010. 
that remain interested in the sport. Our results emphasize the importance of continually reassessing participation by individuals who become inactive to better inform and develop R3 efforts to create more stable purchasing patterns (Price Tack et al. 2018). Moreover, our findings further emphasize the importance of how we think of sportspersons when considering participation and R3 efforts. Retention rates (i.e., 1 - probability of permanently lapsing) of women, for example, differ considerably from men (Fedler and Ditton 2001, Metcalf et al. 2015), with consequences for R3 (Responsive Management and National Shooting Sports Foundation 2017). Recognizing the nuances of why individuals no longer participate in hunting and fishing on a more frequent basis, across larger spatial scales, and among sportsperson activities will help fish and wildlife agencies to better meet the needs of sportspersons (Needham and Vaske 2013, Watkins et al. 2018, Hinrichs 2019).

Perhaps it is not surprising that the Hunter-Angler and Hunter groups were less likely to become inactive, because both groups are more likely to include sportspersons who buy multiple licenses or permits (i.e., cross-buying). Crossbuying is thought to increase customer loyalty or retention (Kamakura et al. 2003), although there is some debate as to whether customers who are more loyal are more likely to engage in cross-buying, or if cross-buying results in increased loyalty (Reinartz et al. 2008). In either case, in Nebraska and elsewhere, hunters spend considerably more money on hunting than anglers do on fishing (U.S. Fish and Wildlife Service 2012), making them less likely to leave an activity in which they are highly invested (i.e., side bets and sunk-cost; Buchanan 1985, Iwasaki and Havitz 2004, Kokko and Jennions 2008, Hrgović and Hromatko 2017). No matter the reason, our results suggest that efforts to transition individuals in the Hunter or Angler groups to the Hunter-Angler group might be an important part of a R3 plan.

We observed that individuals in the largest sportsperson group, Angler, had the lowest retention rates, even though they were greater than the national average (Byrne 2016, Holsman 2016). Efforts focused on angler recruitment often tout how easy it is to start fishing, citing the minimal needs to purchase equipment, the simplicity of learning to be a reasonably successful angler, and the relative ease of access (Responsive Management and National Shooting Sports Foundation 2017); however, new anglers often become inactive (Fedler and Ditton 2001, Byrne 2016). Fishing license sales did increase during our study period (U.S. Fish and Wildlife Service 2017a), but yearly license or permit purchases often are not equivalent to the number of sportspersons in the population (Gude et al. 2012, Schorr et al. 2014). The low retention (i.e., high churn) of anglers may make dependence on fishing license sales particularly susceptible to year-over-year variation in recruitment. Significant differences in annual revenue can make planning for future management challenging because most fish and wildlife agencies operate on annual or biannual budgets. If agencies are concerned about consistency in participation, R3 efforts that help develop more active anglers may be necessary to improve retention rates once an initial interest is developed.

One of the limitations of this study was that we did not model the recruitment of sportspersons. The growth rate of the sportsperson population depends not only on the rate that sportspersons become inactive, but also on the rate at which new sportspersons are recruited. During the timeframe of our assessment, the total number of Nebraska sportspersons remained relatively constant, which suggests adequate recruitment of new hunters and anglers (U.S. Fish and Wildlife Service 2017a,b). It is important, especially if this approach is to be replicated by other fish and wildlife agencies or conservation organizations, that these estimates of transition probabilities are kept in context of recruitment rates. To that end, much of $\mathrm{R} 3$ efforts tend to focus on the recruitment of new hunters and anglers and less attention has been paid to estimates of retention and reactivation (Responsive Management and National Shooting Sports Foundation 2017). Our study places full emphasis on these 2 rates. There are other modelling approaches that could allow the estimation of recruitment rates given electronic licensing systems, such as mark-recapture models (e.g., Gude et al. 2012, Schorr et al. 2014), multistate models (Nichols 2019), stage-structured matrix models (e.g., Price Tack et al. 2018), or integrated population modeling (Riecke et al. 2019). Further, these approaches may allow the integration of covariates into estimating the size of hunter and angler populations providing additional insight into the mechanisms affecting these rates.

Although we did find important differences among the groups we considered, our models did not encompass the complex diversity of the sportsperson population (Arlinghaus et al. 2008, Beardmore et al. 2014, Watkins et al. 2018). Additional consideration of variation in transition rates within license or permit types (e.g., small game, deer) and among other socio-demographic factors (e.g., age, rurality, residency) may greatly improve our understanding of sportsperson participation. Future work should also consider the effect of path dependence on sportsperson transitions. For example, individuals who have purchased licenses or permits for several years may have lower probabilities of becoming inactive. Further research is also needed to link R3 efforts to changes in transition probabilities among categories to better assess existing programs and guide development of new techniques.

Declining participation in hunting and fishing continues to place increased stress on agencies charged with the management of our fish and wildlife resources. Although the development of new funding models may ultimately shape the future of natural resource management, improving our understanding of the underlying patterns driving sportsperson participation rates is important to improving our current management paradigm by helping to prioritize R3 efforts. Although analyses of license and permit purchase patterns cannot inform all policy decisions when it comes to R3 efforts, license and permit data are widely accessible to fish and wildlife agencies; and analyses, such as 
those we present herein, provide an opportunity to highlight opportunities and challenges in R3 efforts.

\section{MANAGEMENT IMPLICATIONS}

Fish and wildlife agencies and nongovernmental organizations (NGOs) are increasingly directing resources toward R3 efforts to increase participation in hunting and fishing. Given the financial challenges, there is a need to optimize R3 efforts that produce the greatest increase of sportsperson participation rates. We recognize the importance of retaining sportspersons beyond license and permit purchases, such as mentoring (Wentz and Seng 2000, Ryan and Shaw 2011, Hinrichs 2019), maintaining cultural traditions (Stedman and Heberlein 2001, Arnett and Southwick 2015), and strengthening customer loyalty (Kamakura et al. 2003, Reinartz et al. 2008). We acknowledge the benefits of retention may not be consistent among sportspersons groups. Clearly, there is a need for a better understanding of sportspersons' purchasing patterns and preferences, which can be done through data mining of electronic license databases. It may benefit organizations that do not currently track participants to adopt systems of tracking participation in hunting and fishing and maintain consistency in data collection and management to inform long-term patterns in participation rates. In addition to using license databases to better understand sportspersons, there is an urgent need to quantify and evaluate R3 objectives. The effectiveness of R3 programs and membership in conservation-type NGOs is often not tracked; thus, it is unknown whether individuals who participate in these activities go on to purchase licenses or permits in the future. Agencies may calculate the likelihood that an individual continues to purchase licenses and permits following attendance of an R3 program or membership to a NGO. Just as population dynamic models of fish and wildlife populations are used to inform management efforts, linking quantitative models of R3 efforts with those of sportsperson dynamics will allow agencies to model or project the influence of R3 efforts on sportsperson populations.

\section{ACKNOWLEDGMENTS}

This project was funded by Federal Aid in Sport Fish Restoration and Federal Aid in Wildlife Restoration project FW-23-R, which was administered by the Nebraska Game and Parks Commission (NGPC). Any use of trade, firm, or product names is for descriptive purposes only and does not imply endorsement by the U.S. Government. CJC was supported by Hatch funds through the Agricultural Research Division at the University of Nebraska-Lincoln and from Federal Aid in Wildlife Restoration project W-120-T, administered by the NGPC. The Nebraska Cooperative Fish and Wildlife Research Unit is jointly supported by a cooperative agreement among the U.S. Geological Survey, the Nebraska Game and Parks Commission, University of Nebraska, the U.S. Fish and Wildlife Service, and the Wildlife Management. We thank the Associate Editor and reviewers for their contributions that greatly improved this manuscript.

\section{LITERATURE CITED}

Arlinghaus, R., M. Bork, and E. Fladung. 2008. Understanding the heterogeneity of recreational anglers across an urban-rural gradient in a metropolitan area (Berlin, Germany), with implications for fisheries management. Fisheries Research 92:53-62.

Arnett, E. B., and R. Southwick. 2015. Economic and social benefits of hunting in North America. International Journal of Environmental Studies 72:734-745.

Baumgartner, R., and T. A. Heberlein. 1981. Process, goal, and social interaction differences in recreation: what makes an activity substitutable. Leisure Sciences 4:443-458.

Beardmore, B., L. M. Hunt, W. Haider, M. Dorow, and R. Arlinghaus. 2014. Effectively managing angler satisfaction in recreational fisheries requires understanding the fish species and the anglers. Canadian Journal of Fisheries and Aquatic Sciences 72:500-513.

Buchanan, T. 1985. Commitment and leisure behavior: a theoretical perspective. Leisure Sciences 7:401-420.

Byrne, B. 2016. Highlights of angler recruitment, retention and reactivation (R3) literature. Bob Byrne Consulting, Amissville, Virginia, USA.

Callegaro, M., and Y. Yang. 2018. The role of surveys in the era of "big data". Pages 175-192 in D. L. Vannette and J. A. Krosnick, editors. The Palgrave handbook of survey research. Palgrave Macmillan, New York, New York, USA.

Collet, J.-F. 2018. Discrete time, countable space. Pages 3-32 in J.-F. Collet, editor. Discrete stochastic processes and applications. Springer International, New York, New York, USA.

Council to Advance Hunting and The Shooting Sports. 2016. National hunting \& shooting sports action plan. Council to Advance Hunting and the Shooting Sports, Washington, D.C., USA.

Ditton, R. B., and S. G. Sutton. 2004. Substitutability in recreational fishing. Human Dimensions of Wildlife 9:87-102.

Fedler, A. J., and R. B. Ditton. 2001. Dropping out and dropping in: a study of factors for changing recreational fishing participation. North American Journal of Fisheries Management 21:283-292.

Fontaine, J. J., A. D. Fedele, L. S. Wszola, L. N. Messinger, C. J. Chizinski, J. J. Lusk, K. L. Decker, J. S. Taylor, and E. F. Stuber. 2019. Hunters and their perceptions of public access: a view from afield. Journal of Fish and Wildlife Management 10:1-13.

Galea, S., and M. Tracy. 2007. Participation rates in epidemiologic studies. Annals of Epidemiology 17:643-653.

Gelman, A., and C. R. Shalizi. 2013. Philosophy and the practice of Bayesian statistics. British Journal of Mathematical and Statistical Psychology 66:8-38.

Gude, J. A., J. A. Cunningham, J. T. Herbert, and T. Baumeister. 2012. Deer and elk hunter recruitment, retention, and participation trends in Montana. Journal of Wildlife Management 76:471-479.

Hinrichs, M. 2019. Hunter and angler motivations, preferences, and barriers to waterfowl hunting in the central United States. Thesis, University of Nebraska-Lincoln, Lincoln, USA.

Holsman, R. H. 2016. What the evidence suggests for the future of fishing and hunting license sales in Wisconsin. Wisconsin Department of Natural Resources-Social Science Service Sector, Madison, Wisconsin, USA. https://dnr.wi.gov/files/PDF/pubs/ss/SS1164.pdf. Accessed 4 Jun 2018.

Hrgović, J., and I. Hromatko. 2017. The time and social context in sunkcost effect. Evolutionary Psychological Science 4:1-10.

Huang, J. L., M. Liu, and N. A. Bowling. 2014. Insufficient effort responding: examining an insidious confound in survey data. Journal of Applied Psychology 100:828-845.

Iwasaki, Y., and M. E. Havitz. 2004. Examining relationships between leisure involvement, psychological commitment, and loyalty to a recreation agency. Journal of Leisure Research 36:45-72.

Kamakura, W. A., M. Wedel, F. de Rosa, and J. A. Mazzon. 2003. Crossselling through database marketing: a mixed data factor analyzer for data augmentation and prediction. International Journal of Research in Marketing 20:45-65.

Karlin, S., and H. M. Taylor. 1975. A first course in stochastic processes. Academic Press, San Diego, California, USA.

Kokko, H., and M. D. Jennions. 2008. Parental investment, sexual selection and sex ratios. Journal of Evolutionary Biology 21:919-948.

Kuehn, D., V. Luzadis, and M. Brincka. 2013. An analysis of the factors influencing fishing participation by resident anglers. Human Dimensions of Wildlife 18:322-339. 
Laborde, L. P., F. C. Rohwer, M. D. Kaller, and L. A. Reynolds. 2014. Surveying Louisiana waterfowl hunters: open web and random mail surveys produce similar responses to attitudinal questions. Wildlife Society Bulletin 38:821-826.

Meade, A. W., and S. B. Craig. 2012. Identifying careless responses in survey data. Psychological Methods 17:437-455.

Metcalf, E. C., A. R. Graefe, N. E. Trauntvein, and R. C. Burns. 2015. Understanding hunting constraints and negotiation strategies: a typology of female hunters. Human Dimensions of Wildlife 20:30-46.

Miller, C. A., and A. R. Graefe. 2000. Degree and range of specialization across related hunting activities. Leisure Sciences 22:195-204.

Needham, M. D., and J. J. Vaske. 2013. Activity substitutability and degree of specialization among deer and elk hunters in multiple states. Leisure Sciences 35:235-255.

Nichols, J. D. 2019. Confronting uncertainty: contributions of the wildlife profession to the broader scientific community. Journal of Wildlife Management 83:519-533.

Price Tack, J. L., C. P. McGowan, S. S. Ditchkoff, W. C. Morse, and O. J. Robinson. 2018. Managing the vanishing North American hunter: a novel framework to address declines in hunters and hunter-generated conservation funds. Human Dimensions of Wildlife 23:515-532.

Quartuch, M. R., R. C. Stedman, D. J. Decker, W. F. Siemer, and M. S. Baumer. 2016. Taking a non-traditional path to hunting in New York: insights and implications for recruitment and retention. Human Dimensions Research Unit Series No 16-2. Cornell University Department of Natural Resources, Ithaca, New York, USA.

R Core Team. 2018. R: a language and environment for statistical computing. R Foundation for Statistical Computing, Vienna, Austria.

Reinartz, W., J. S. Thomas, and G. Bascoul. 2008. Investigating cross-buying and customer loyalty. Journal of Interactive Marketing 22:1-16.

Responsive Management and National Shooting Sports Foundation. 2017. Hunting, fishing, sport shooting, and archery recruitment, retention, and reactivation: a practitioner's guide. Responsive Management and National Shooting Sports Foundation, Harrisburg, Virginia, USA.

Riecke, T. V., P. J. Williams, T. L. Behnke, D. Gibson, A. G. Leach, B. S. Sedinger, and J. S. Sedinger. 2019. Integrated population models: model assumptions and inference. Methods in Ecology and Evolution 10:1072-1082.

Roberts, C. 2007. Mixing modes of data collection in surveys: a methodological review. Economic and Social Research Council National Centre for Research Methods. NCRM Methods Review Paper (Unpublished). City University, London, United Kingdom. http://www.ncrm.ac.uk/research/ outputs/publications/methodsreview/MethodsReviewPaperNCRM-008. pdf. Accessed 4 Jun 2018.

Rogelberg, S. G., and J. M. Stanton. 2007. Introduction: understanding and dealing with organizational survey nonresponse. Organizational Research Methods 10:195-209.

Ryan, E. L., and B. Shaw. 2011. Improving hunter recruitment and retention. Human Dimensions of Wildlife 16:311-317.

Schorr, R. A., P. M. Lukacs, and J. A. Gude. 2014. The Montana deer and elk hunting population: the importance of cohort group, license price, and population demographics on hunter retention, recruitment, and population change. Journal of Wildlife Management 78:944-952.

Southwick Associates. 2015a. A portrait of hunters and hunting license trends: national report. Produced for the National Hunting and Shooting Sports. http://www.michigandnr.com/FTP/wildlife/aversb/ MWL/Hunting_Heritage/Southwick\%20NSSF\%20Hunter\%20Churn \%20Nat1\%20Report.pdf. Accessed 10 Jul 2018.

Southwick Associates. 2015b. Annual churn rates and composition of the angler population: by region 2009 to 2013. Southwick Associates and National Shooting Sports Foundation, Fernandina Beach, Florida, USA.

Southwick Associates and National Shooting Sports Foundation. 2010. A portrait of hunters and hunting license trends: national report. Southwick Associates and National Shooting Sports Foundation, Fernandina Beach, Florida, USA.

Spedicato, G. A. 2017. Discrete time Markov chains with R. The R Journal 9:21.

Stedman, R. C., and T. A. Heberlein. 2001. Hunting and rural socialization: contingent effects of the rural setting on hunting participation. Rural Sociology 66:599-617.

U.S. Fish and Wildlife Service. 1993. 1991 national survey of fishing, hunting, and wildlife-associated recreation. U.S. Fish and Wildlife Service, Washington, D.C., USA.

U.S. Fish and Wildlife Service. 2012. 2011 national survey of fishing, hunting, and wildlife-associated recreation. U.S. Fish and Wildlife Service, Washington, D.C., USA.

U.S. Fish and Wildlife Service. 2017a. National fishing license data. U.S. Fish and Wildlife Service, Washington, D.C., USA.

U.S. Fish and Wildlife Service. 2017b. National hunting license data. U.S. Fish and Wildlife Service, Washington, D.C., USA.

U.S. Fish and Wildlife Service. 2018. 2016 national survey of fishing, hunting, and wildlife-associated recreation. U.S. Fish and Wildlife Service, Washington, D.C., USA.

Vaske, J. J., M. P. Donnelly, and B. Shelby. 1990. Comparing two approaches for identifying recreation activity substitutes. Leisure Sciences 12:289-302.

Vrtiska, M. P., J. H. Gammonley, L. W. Naylor, and A. H. Raedeke. 2013. Economic and conservation ramifications from the decline of waterfowl hunters. Wildlife Society Bulletin 37:380-388.

Watkins, C., N. C. Poudyal, C. Caplenor, D. Buehler, and R. Applegate. 2018. Motivations and support for regulations: a typology of eastern wild turkey hunters. Human Dimensions of Wildlife 23:433-445.

Wentz, J., and P. Seng. 2000. Meeting the challenge to increase participation in hunting and shooting. National Shooting Sports Foundation \& International Hunter Education Association, Newtown, Connecticut, USA.

Winkler, R., and K. Warnke. 2013. The future of hunting: an age-periodcohort analysis of deer hunter decline. Populations and Environment 34:460-480.

Winston, W. L. 1994. Operations research: applications and algorithms. Third edition. Duxbury Press, Belmont, California, USA.

Associate Editor: Miller. 